\title{
METABOLISMO DAS BACTÉRIAS
}

1. INTRODUÇÃO

2. METABOLISMO ENERGETICO 2.1. Considerações Gerais

2.2. O ATP

2.3. Metabolismo dos Carboidratos

1.3.1. Digestão

2.3.2. Degradação

a) Anaeróbia

b) Aeróbia

3. METABOLISMO PLÁSTICO

3.1. Considerações Gerais

3.2. Metabolismo das Proteínas

4. ESQUEMA GERAL' DO METABOLISMO

\section{SINOPSE}

Estudo e descrição do Metabolismo das bactérias.

Subsídios e material de estudo para os alunos que cursam as disciplinas de Microbiologia nos cursos de Odontologia.
Eduardo Roberto Corrêa de Barros Auxiliar de Ensino do Departamento de Odontologia Preventiva e Social

Associação dos fenômenos metabólicos das bactérias com os processos patológicos mais comuns em odontologia: cárie com suas conseqüências e doença periodontal.

\section{INTRODUÇ̃̃O}

Os princípios básicos do metabolismo e bioquimismo não variam entre os sêres vivos. Contudo, muitas diferenças ocorrem no desenvolvimento geral dos processos, considerando-se microrganismos, animais ou vegetais. $^{6}$

Tendo em vista que o estudante de Odontologia está familiarizado com os processos gerais do metabolismo e conhecimentos básicos de bioquímica, pretendemos descrever ùnicamente os processos microbianos e em específico os bacterianos, sem um aprofundamento maior na parte referente a bioquímica.

Entende-se por METABOLISMO a 
totalidade das reações químicas que ocorrem nas células vivas. Êle compreende duas fases distintas: o ANABOLISMO ou assimilação e o CATABOLISMO ou desassimilação.

Dois aspectos básicos devem ser considerados no metabolismo: - a energia (METABOLISMO ENERGÉTICO) e a biossíntese (METABOLISMO PLÁstICO). ${ }^{7}$,

\section{METABOLISMO ENERGÉTICO}

\subsection{CONSIDERAÇÕES GERAIS}

E através de reações metabólicas, sôbre produtos retirados do meio ambiente, que as bactérias vão produzir a energia que será utilizada na biossintese e no crescimento, bem como em atividades secundárias como a mobilidade, luminescência e calor. 6

Dependendo do «habitat» natural da bactéria, ela irá obter essa energia de diferentes modos:

- vivendo em meio inorgânico (bactérias autotróficas) a energia será obtida pela metabolização do $\mathrm{CO}_{2}$ atmosférico através de reações de fotossintese e quimiossíntese;

- vivendo em meio orgânico (bactérias heterotróficas) a energia será obtida pela metabolização de compostos orgânicos através de reações de quimiossíntese. ${ }^{2}$

Uma vez que as bactérias que ha- bitam a cavidade oral, razão de nosso estudo, são exclusivamente heterotróficas, vamos nos deter sòmente no processo quimiossintético.

As bactérias heterotróficas, as quais compõem a quase totalidade das bactérias encontradas na natureza, utilizam-se de material orgânico complexo como fonte de energia (alimentos energéticos). ${ }^{1}$ Os compostos mais largemente utilizados são os CARBoIdratos. Seguem-se, em ordem de importância, os protídeos e lipídeos. 8

O metabolismo energético consiste em uma série de reações de redução e oxidação (REDOX). Recorde-se que a OXIDAÇÃO é definida como a remoção de elétrons de um substrato, com a conseqüiente remoção de íons hidrogênio, resultando um produto oxidado (doador de $\mathrm{H}$ ) e a liberação de energia aproveitável pela célula.c

J'á a REDUÇÃO consiste no inverso da oxidação, isto é, a recepção de elétrons (podendo aceitar também os íons $\mathrm{H}$ ) por um determinado substrato (receptor de $\mathrm{H}$ ). Neste caso, ao efetuar-se a reação, haverá consumo de energia. 6

As oxidações biológicas em geral, são classificadas em tipos, segundo a natureza do receptor final do hidrogênio ${ }^{6}$ :

\section{1 - RESPIRAÇÃO AERóBIA - quando o receptor final do $\mathrm{H}$ é o oxigênio molecular. Ocorre naquelas bactérias que vivem em presença do ar atmosférico (bactérias aeróbias).}


? - RESPIRAÇÃO ANAERóBIA OU FERMENTAÇÃO (*) - quando o receptor final do $\mathrm{H}$ é qualquer composto orgânico ou inorgânico que não o $\mathrm{O}_{2}$. Ocorre naquelas bactérias que vivem na ausência do ar atmosférico (bactérias anaeróbias).

Prèviamente ao estudo do metabolismo dos carboidratos, exemplo que daremos ao metabolismo energético, por ser o mais freqüente, vejamos d€ que forma as bactérias são capazes de acumular energia: é necessário que recordemos o ATP.

\subsection{O A T P}

O ATP (Adenosina Tri Fosfato) é uma molécula complexa que existe, é formada ou consumida parcialmente no corpo bacteriano e nos sêres vivos em geral, na qual se armazena a maior parte da energia. Êsse armazenamento ocorre na forma de ligações de radicais fosfato. A molécula de ATP é constituída bàsicamente de uma base púrica e ribose às quais se ligam os radicais fosfato (com ligações ricas em energia). ${ }^{8}, 11$
$\mathrm{N}=\mathrm{C}-\mathrm{NH}_{2}$
$\mathrm{CH} \quad \mathrm{C}-\mathrm{NH}$
$\mathrm{N}-\mathrm{C}-\mathrm{N}>\mathrm{CH}$

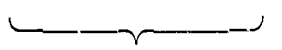

Adenina

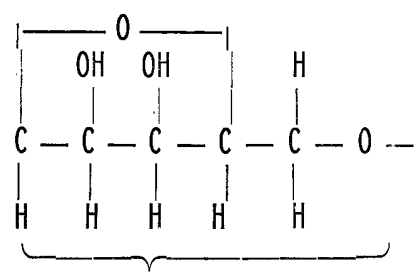

Ribose

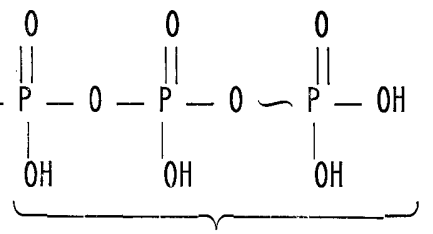

3 Fosfatos

Ou, esquemàticamente:

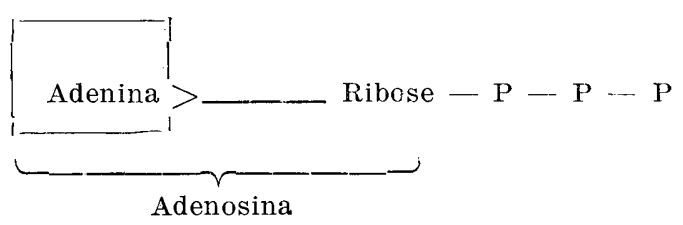

(*) Jawetz, distingue a Respiração Anaeróbia da Fermentação do seguinte modo: - Respirasão Anaeróbia - o receptor final do H é qualquer substância inorgânica que não $\mathrm{O}_{2}$.

-. Fermentação - o receptor final do H é l:m composto orgânico.

R. Fac. Odont. P. A. 
Quando só um radical fosfato se liga à Adenosina, temos o AMP (adenosina monofosfato ou ácido adenílico); sendo dois os radicais fosfatos ligados, temos o ADP (adenosina difosfato) e no caso de três temos o ATP (adenosina tri-fosfato). Enquanto a molécula está sendo sintetizada $(\mathrm{AMP} \rightarrow \mathrm{ADP} \rightarrow \mathrm{ATP})$ está havendo acúmulo de energia (anabolismo energético). Quando ela está perdendo os radicais fosfato, está liberando energia (catabolismo energético).

Esta alta energia que a bactéria acumula através da molécula de ATP, ela a usa para desdobrar moléculas complexas em simples a fim de que possam ser metabolizada.8

\subsection{METABOLISMO DOS CARBOIDRATOS}

\subsubsection{Digestão}

Os microrganismos heterotróficos utilizam os compostos orgânicos como fonte de energia; dêstes, sobretudo os açúcares (carboidratos). Os açúcares são aproveitados pela célula bacteriana, em geral, na forma de hexoses como a glicose, a galactose e a frutose, mas principalmente na forma de glicose. Assim sendo, há a necessidade, por parte dos microrganismos, de quebrar as grandes moléculas dos compostos complexos (ex.: amido) por meio de suas enzimas extraselulares (reações de hidrólise) transformando-os em produtos simples (monossacarídeos como a glicose). Esta primeira fase da digestão, quer ocorra no trato alimentar dos organismos superiores ou no meio em tôrno da célula bacteriana, visa fragmentar o substrato ém partículas suficientemente pequenas para penetrar na célula. 6

A segunda fase da digestão vai ocorrer na membrana celular, local onde se encontram os «transportadores», proteínas que selecionam o material a penetrar no citoplasma bacteriano, conduzindo-o da superfície externa da membrana para a sua superfície interna. A isso denominamos de TRANSPORTE ATIVO; sua função é evitar a simples difusão através da membrana (transporte passivo) o que poderia limitar grandemente a taxa do metabolismo. ${ }^{1,0}$ (Figs.: 1 e 2)

\subsubsection{Degradação}

Uma vez no interior da massa citoplasmática, o carboidrato poderá ser degradado através de diferentes vias (modos diversos):

- $1^{a}$ Via: Fosforilativa:

a) Via Glicolítica

b) Vía Oxidativa das Pentoses Fosfatos

c) Vía De-hidrativa

- 2. Via: Oxidado e após

Fosforilado

- $3^{\alpha}$ Via: Oxidado e Metabolizado (sem fosforilação). ${ }^{1}$

De tôdes estas vias de degradação, a risis importante é a vía FOSFORILATIVA e nesta a sub-vía denominada de GLICOLítTICA ou GLICóLISE por sua maior freqüên- 
FIG. I CÉLULA BACTERIANA
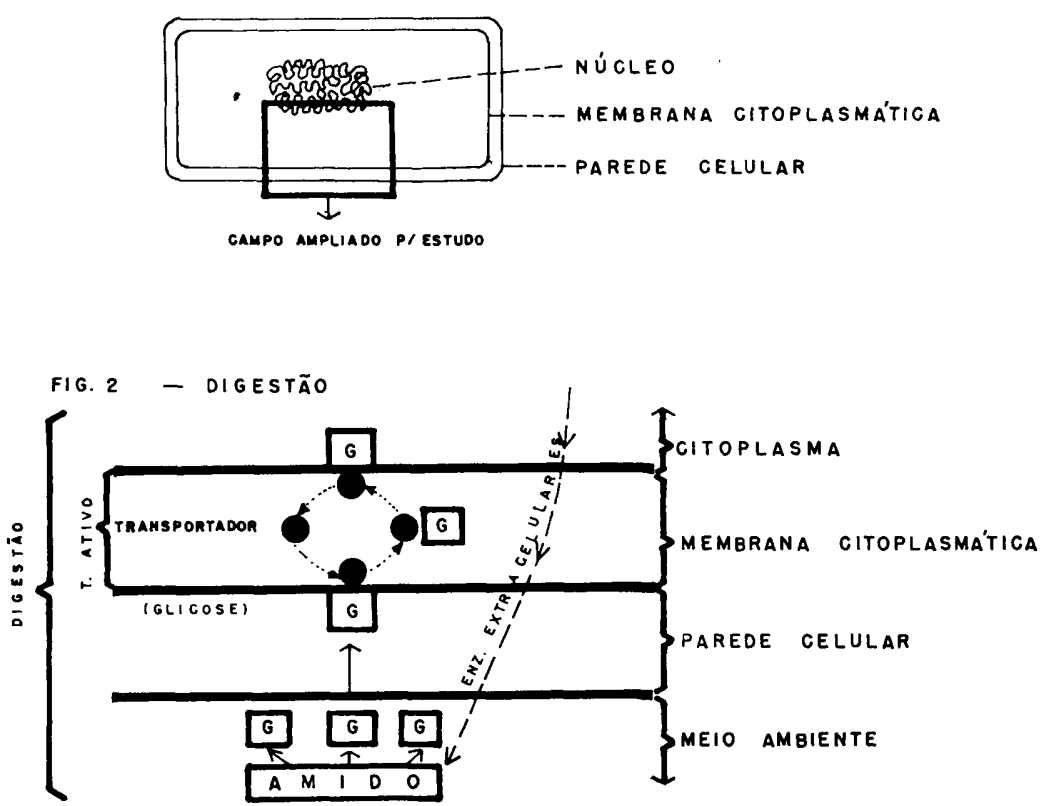

cia. Vejamos o seu desenvolvimento: - uma vez rompidas as grandes moléculas do composto (ex.: amido) a hexose penetra no citoplasma bacteriano (digestão) onde é fosforilada, isto é, ela entra em contato com uma molécula de ATP da célula bacteriana e, por ação enzimática, re.move desta molécula um radical fosfato para si, devolvendo o restante à bactéria: ADP. Uma das razões básicas para que ocorra esta fosforilação é a fixação da hexose dentro do citoplasma; não ocorrendo, a hexose assim como entrou, poderia sair da intimidade celular.
A GLICólise, também conhecida como ciclo de EMBDEN-MEYERHOF-PARNAS (EMP), consiste na decomposição da molécula de Glicose até ÁCIDO PIRÚvico. Ao desenvolver-se êste ciclo (com cêrca de 11 produtos intermediários), uma molécula de hexose (glicose) dá duas moléculas de triose (ácido pirúvico). Para tanto, a bactéria gasta 2 ATPs no inicio do ciclo e ganha 4 em sua fase final. O saldo energético proveniente da glicólise é, portanto, de 2 ATPs. Ainda durante o ciclo, ocorre a liberação de $2 \mathrm{H}++$ que não entram em reação. ${ }^{1,}{ }^{3},{ }^{8}, 10$, 11

R. Fac. Odont. P. A. 


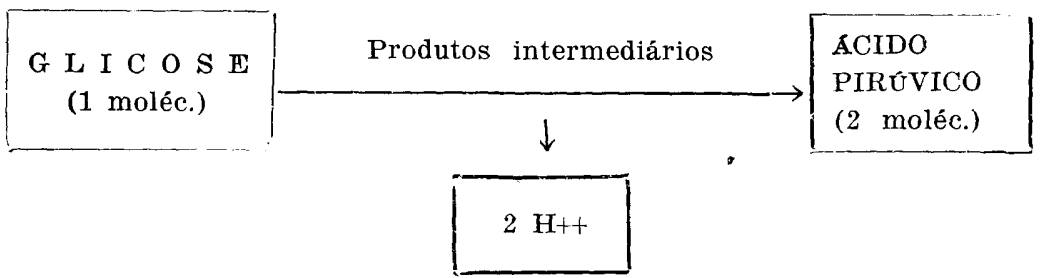

Esta via é usada normalmente por todos os microrganismos, tanto AERóBIOS como ANAERóBIOS.

Mas, as bactérias não aproveitam o ácido pirúvico como produto final, por isso devem continuar a degradá1o. Isso vai ocorrer conforme o tipo respiratório do microrganismo: aeróbio ou anaeróbio.
A bactéria sendo ANAERóBIA, irá utilizá-lo através de FERMENTAÇõES e sendo AERóBIA a utilização se fará através do chamado CICLO DE KREBS e CADEIA RESPIRATÓRIA.

Diagrama Geral da Metabolização de Carboidratos: 8

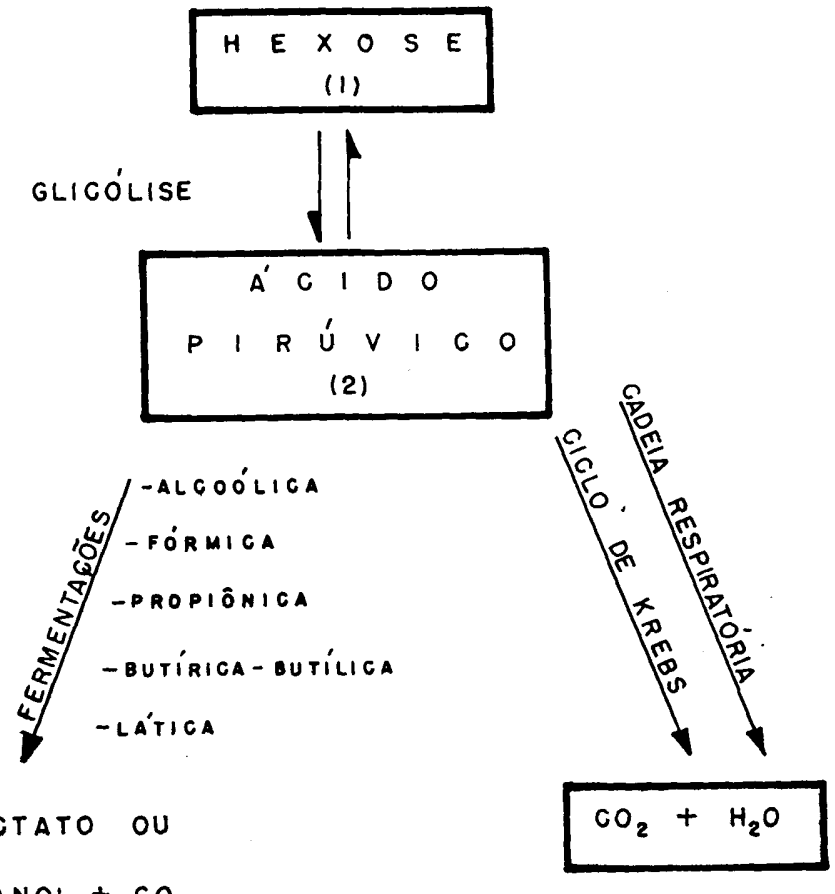

ETANOL + CO...

BACT. ANAERÓBIAS

BACT. AERÓBIAS

BACT. FACULTATIVAS $\left(\operatorname{sem} \mathrm{O}_{2}\right.$ )
BACT. FACULTATIVAS $\left(\operatorname{com} \mathrm{O}_{2}\right)$

R. Fac. Odont. P. A. 


\section{a) DEGRADAÇ̃̃ ANAERÓBIA}

As bactérias anaeróbias degradam o ácido pirúvico de diversas formas, o que constitui os diferentes tipos de fermentações citados a seguir: 4,8

\section{1 - FERMENTAÇÃO ALCOóliCA -} o produto final é o álcool etílico $\left(\mathrm{CH}_{3} \mathrm{CH}_{2} \mathrm{OH}\right)$, E um tipo de fermentação produzido p e 1 a maioria das bactérias fermentativas.

\section{2 - FERMENTAÇÃO FóRMiCA -} é mais complexa: o ácido fórmico é o ( $\mathrm{H}$ COOH $)$ produto característico, além de outros que aparecem em quantidades variáveis: ácido acético, etanol e butileno-glicol na «fermentação fórmica butileno-glicol». São produzidas em geral pelas enterobactérias.

\section{3 - FERMENTAÇÃO BUTÍRICA-} BUTÍLICA - é ainda mais complexa que a anterior. Ê caracterizada pela formação de três compostos de 4 átomos de carbono: butano, ácido butírico, ácido acetoacético e mais ácido acético, acetona e etanol. É produzida por microrganismos do gênero Clostridium.
4 - FERMENTAĈ̃̃O PROPIONICA onde o açúcar é convertido em ácido propiônico, acético, sucsínico, $\mathrm{CO}_{2}$ e algum ácido lático. É própria do Propionibacte. rium pentosaceum e Veillonella gazogenes.

5 - FERMENTAÇ̃̃O LÁTICA -
que pode ser: 7 H O M O F E R M E N TATIVA Quando há ùnicamente a formação de ácido lático. É te.mbém conhecida como fermentação homolática e é produzida especialmente por Streptococeus e Lactobacillus casei

\section{HETEROFERMENTATIVA - Quando há a formação, além do ácido lático, de ácido acé- tico e fórmico, etanol, glice- rol e $\mathrm{CO}_{2}$. É também chamada de heterolática e em geral é produzida pelos Lactobacil. lus.}

A ocorrência fundamental neste tipo de fermentação (que nos interessa de perto), é que os ${ }^{2} \mathrm{H}++$ que haviam sido liberados na glicólise, são aceptados pela enzima NAD (nicotinamida adenina dinucleotídeo). Esta, acopla os ${ }^{2} \mathrm{H}++$ às duas moléculas de ácido pirúvico (trioses) dando duas moléculas de ácido lático. 1,11

$2 \mathrm{CH}_{3} \mathrm{CO} \mathrm{COOH}+2 \mathrm{NADH}_{2} \longrightarrow 2 \mathrm{CH}_{3} \mathrm{CHOH} \mathrm{COOH}+2 \mathrm{NAD}$ 
Em ODONTOLOGIA, o estudo das fermentações tem grande importância, pois é através delas que se formam áciảos como produtos finais. Em última análise, êstes são os apontados como os responsáveis pela destruição ou desintegração da parte mineral, da parte dura do dente (CÂRIE),

Assim, sabendo-sé que a fermentação é possível sòmente em presença de açúcares, pretende-se evitá-la através de uma higiene bucal correta, dieta adequada etc.

Em especial destacamos as fermentações homo e heterofermentativas que são produzidas pelos estreptococos e lactobacilos. Os estreptococos são os mais encontradiços na fase inicial dos processos cariosos e por isso mesmo são considerados, atualmente, como seus agentes etiológicos, já que atuando sôbre restos de açúcares formam o ácido lático. Além do mais, em trabalhos com animais gnotobióticos, foram os únicos microrganismos a determinar a formação de cárie dental. 5

Outros produtos das fermentações servem para auxiliar na identificação das bactérias como: ácido acéti$\mathrm{co}$, lático, fórmico, etanol, $\mathrm{CO}_{2}$, ácido butírico, butanol, ácido isopropilico, ácido propiônico, acetona, acetil-metil-carbinol, 2-3 butileno-glicol etc. Êstes dois últimos produtos, por exemplo, servem para diferenciar bioquìmicamente duas espécies de microrganismos, a Escherichia coli e o Aerobacter aerogenes, ambos enterobactérias. Isto é realizado por

$$
\text { glicólise }
$$

provas em que o produto final, acima citado, é pesquisado por um corante, o vermelho de metila. As provas são denominadas de VM e VP (vermelho de metila e Voges Proskauer).

Quanto ao aspecto energético, nas fermentações estabelece-se um equilíbrio tal que não há perda ou ganho de energia pelas bactérias. Resta-lhes apenas os ATPs ganhos quando da glicólise (2 ATPs). Ao contrário, nas chamadas «fermentações oxidativas», ou seja, a degradação aeróbia dos açúcares, o rendimento energético é bastante alto. 2,8

\section{b) DEGRADACÃo AERóBLA}

Em presença do oxigênio, as bactérias atuam sôbre a glicose produzindo sua degradação pelo esquema de EMP, formando o mesmo produto intermediário que é o ácido pirúvico (exatamente como as anaeróbias). Entretanto, o caminho que segue a degradação do ácido pirúvico pelas aeróbias é diferente pois elas possuem sistemas enzimáticos que as ¿naeróbias não possuem. Neste caso, os $2 \mathrm{H}++$ liberados na glicólise são levados pela NAD a outras enzimas próprias da respiração como as flavoproteínas $(\mathrm{Fp})$ e citocromos, combinando-se com o $\mathrm{O}_{2}$ e dando $\mathrm{H}_{2} \mathrm{O}$ (é a cadeia respiratória).

Conseqüentemente, o ácido pirúvico não é reduzido a lático e passa a tomar parte em outro ciclo chamado de «Ciclo dos ácidos tricarboxílicos» ou «Ciclo de Krebs». 1,3,8, 11

Ciclo de Krebs

Cadeia Respiratória

$$
\mathrm{CO}_{2}+\mathrm{H}_{2} \mathrm{O}
$$




\section{ASPECTO ENERGÉTICO}

Durante o ciclo dos ácidos tricarboxílicos há armazenamento de energia sob a forma de ATP, o que ocorre durante a transferência de elétrons para $\mathrm{O} \mathrm{O}_{2}$, pois conforme acentuamos, êste ciclo se desenvolve ùnicamente em presença do oxigênio.

Dêste modo, incluindo a fase inicial (Ciclo de EMP) e a fase final com duas etapas (Ciclo de Krebs e Cadeia Respiratória) teremos a formação de 19 ATPs por triose. Logo, 1 mól de glicose (hexose) formará 38 ATPs.

\section{Resumindo: \\ $1^{\alpha}$ fase: Glicólise ... 2 ATPs \\ $2^{\alpha}$ fase: C i c l o d e Krebs .... 30 ATPs \\ $3^{\alpha}$ fase: Cadeia Res- piratória ... 6 ATPs T O T A L . 38 ATPS}

Queimando-se 1 mól de glicose obtém-se 686.000 cal. Forma-se, no entanto, 38 ATPs que correspondem a 397.480 cal e esta é a energia útil, a reservada. 8

\section{ENZIMAS DA RESPIRACÃO}

Vimos até aqui o mecanismo da degradação dos carboidratos, ou seja, a oxidação dêste substrato com formação energética quer em presença de $\mathrm{O}_{2}$, quer na ausência do mesmo.

Tôdas as reações estudadas são promovidas por enzimas especiais, é óbvio. Em ANAEROBIOSE, acentuamos que todos os elétrons do substrato são utilizados na formação de diversas substâncias complexas por intermédio de enzimas NAD. Em AEROBIO$\mathrm{SE}$, em que as bactérias possuem algumas enzimas próprias, os elétrons retirados do substrato são conduzidos através delas, em cadeia até o $\mathrm{O}_{2}$, formando $\mathrm{H}_{2} \mathrm{O}$ e $\mathrm{CO}_{2}$. As enzimas que atuam nestes processos de oxidação aeróbia são: NAD, NADP (nicotinamida adenina dinucleotídeo fosfato) e mais:

FAD - flavina adenina dinucleotídeo,

FMN - flavina mononucleotídeo,

Fp - flavoproteínas (contendo FAD) e enzimas contendo ferro (ferroporfirinas) que compreende os citocromos a, $\mathrm{a}_{1}, \mathrm{a}_{2}{ }^{\mathrm{a}_{3}}$ (oxidase), $\mathrm{a}_{4}$, de $b a_{7}$ e de $c$ a $c_{5}, f, h$, catalase e peroxidases.

Tôdas estas enzimas têm a capacidade de receber e doar elétrons, isto é, possuem um potencial «redox» e estão dentro de um sistema que permite serem acopladas.

As diferenças de seus potenciais «redox» são pequenas e isto dá origem a que os elétrons «saltem» de uma enzima a outra, constituindo uma cadeia de enzimas que é a chamada «Cadeia Respiratória». ${ }^{8}$

\section{CADEIA RESPIRATÓRIA}

Estudos sucessivos de Keilin e de Warburg com o intuito de conhecer as enzimas transportadoras de elétrons e seus potenciais «redox», permitiram estabelecer a cadeia respiratória como segue: 8 


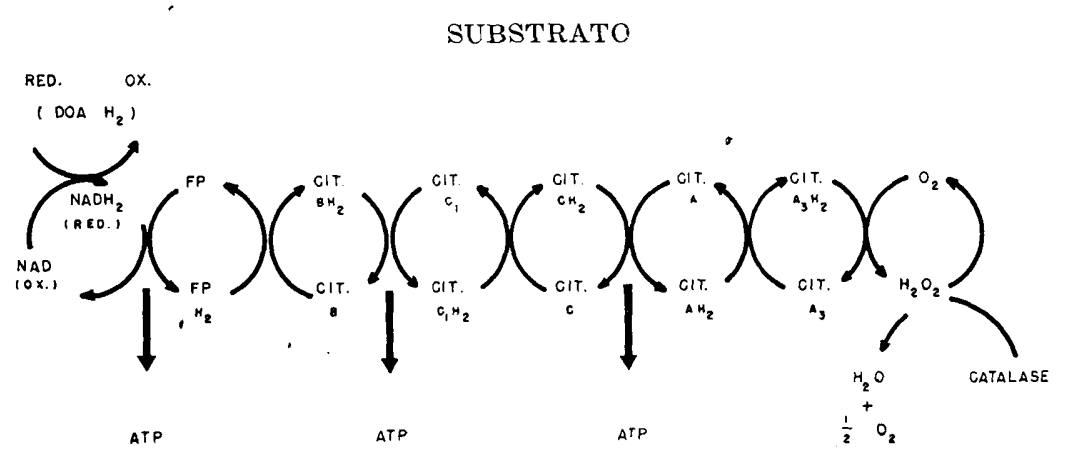

Conforme êste esquema, os átomos de hidrogênio provenientes do substrato são recebidos pelo NAD que se reduz $\left(\mathrm{NADH}_{2}\right)$. Segue-se a passagem às flavoproteínas e aos citocromos até $0 a_{3}$ quando o elétron é liberado e combina-se com $\mathrm{O}_{2}$ formando $\mathrm{H}_{2} \mathrm{O}_{2}$ (água oxigenada). Êste $\mathrm{H}_{2} \mathrm{O}_{2}$ é desdobrado nas bactérias aeróbias em $\mathrm{H}_{2} \mathrm{O}+1 / 2 \mathrm{O}_{2}$ por ação da CATALASE (as anaeróbias, quando ao ar livre, podem chegar a realizar parte do processo, mas, por não terem catalase, acumulam o $\mathrm{H}_{2} \mathrm{O}_{2}$ e morrem). ${ }^{8}$

\section{TIPOS RESPIRATóRIOS}

Os tipos respiratórios das bactérias são classificados em relação ao $\mathrm{O}_{2}$ e podem ser definidos da seguinte forma: 2

BACTÉRIAS AERóBIAS - as que crescem sòmente em presença de $\mathrm{O}_{2}$;

BACTÉRIAS ANAERÓB'IAS - as que crescem só na ausência de $\mathrm{O}_{2} \mathrm{e}$

\section{BACTERIAS FACULTATIVAS -} as que crescem tanto na presença como na ausência do $\mathrm{O}_{2}$.

Algumas bactérias exigem uma pequena quantidade de $\mathrm{O}_{2}$ e por isso são denominadas de MICROAERófILAS.

\section{Metabolisho PLâstico}

\subsection{CONSIDERAÇOEES GERAIS}

o segundo aspecto básico a ser considerado no metabolismo é a biossíntese. É através da metabolização das macromoléculas que a bactéria forma os seus próprios constituintes, estando pois, apta a crescer e a multiplicar-se. Para tanto ela necessita de alimentos plásticos (assim como necessitou dos energéticos). Entre êles, em primeiro plano encontram-se as PROTEÍNAS. $\quad 6,8$ 


\subsection{METABOLISMO DAS PROTEINAS}

A decomposição dos compostos nitrogenados orgânicos por bactérias denomina-se de PUTREFAC Ã O. o mecanismo de degradação das proteínas foi conhecido através do estudo das reacoões de síntese das mesmas. Embora elas ainda não estejam totalmente definidas, podemos esboçá-las. É um metabolismo diverso daquele dos carboidratos no aspecto de sua esquematização, pois as bactérias não são uniformes na ação de degradar êstes compostos. Baseados então, no inverso da síntese das proteínas, é que teceremos algumas consideracões. 1,3

As proteínas do substrato, poli- peptídeos que são, ao sofrerem a ação das enzimas extracelulares das bactérias, vão sendo degradadas em compostos mais simples: peptídeos e aminoácidos. Durante estas transformações das macromoléculas, restam no substrato muitos produtos da degradação como: $\mathrm{H}_{2} \mathrm{~S}$, indol, escatol, radicais $\mathrm{NH}_{3}$ e gases como o $\mathrm{CC}_{2}$.

Os aminoácidos, moléculas mais simples, é que serão aproveitados pelas bactérias. Vai ocorrer a d i g e stão dessas moléculas através do «transporte ativo». 1,6

Uma vez no interior do citoplasma bacteriano, as moléculas de aminoácidos serão reagrupadas em peptídeos, polipeptídeos e nas PROTEíNAS DA BACTÉRIA. (fig. 3)

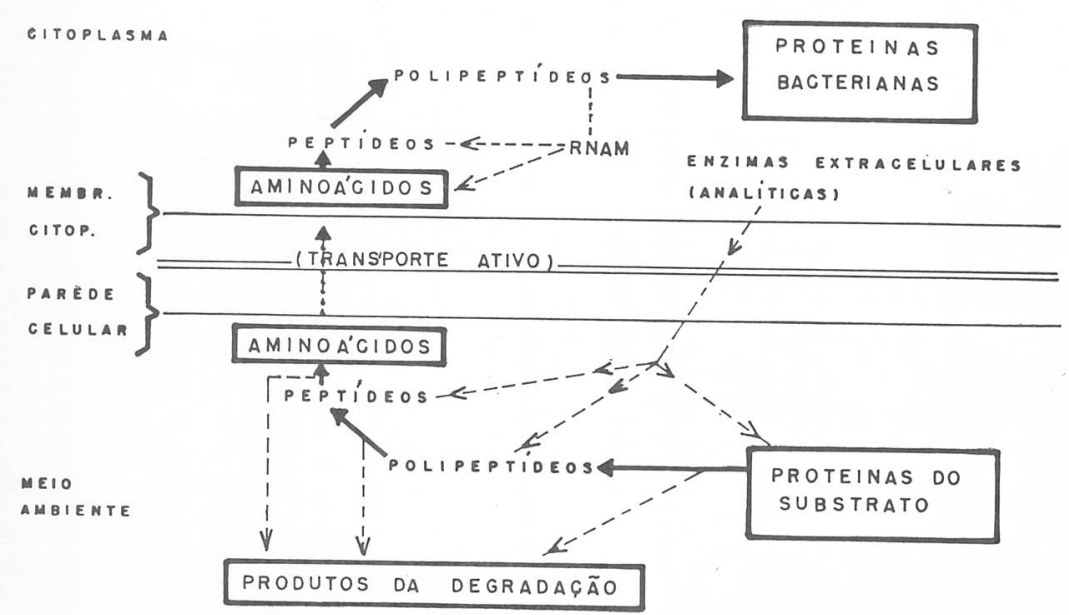

R. Fac. Odont. P. A. 
Segundo Jawetz, esta síntese protéica ocorre do seguinte modo: «usando uma molécula de DNA como molde, uma enzima RNA polimerase forma um cordão de poli-ribonucleotídeos, chamado RNA mensageiro (RNAm). Esste, tem uma sequiência complementar para cada um dos filamentos da dupla hélice de DNA». 6
O RNAm, por sua vez, vai servir como molde para a síntese de proteínas (fig. 4).

Oatros produtos de degradação constam de: putrescina, cadaverina e ptomainas. Substâncias estas formadas no interior do citoplasma e que são liberadas para meio.

RNA polimerase
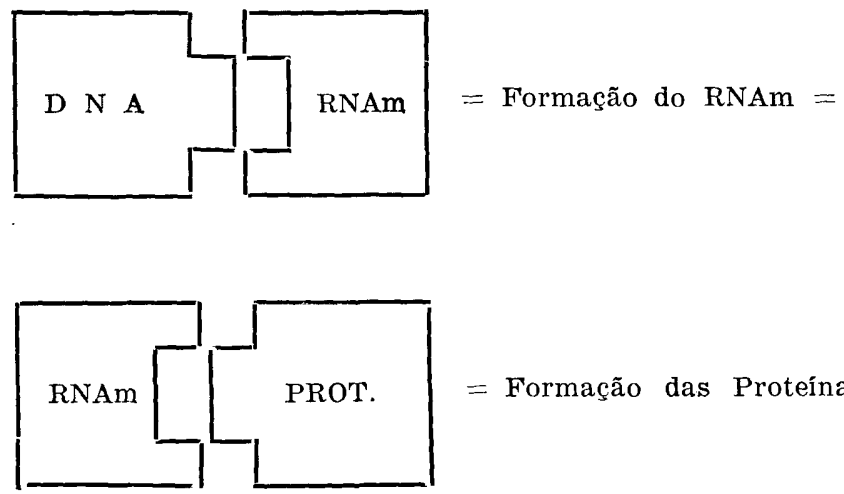

$=$ Formação das Proteínas =

As enzimas que atuam neste processo degradativo podem ser grupadas em HIDROLASES e DESMOLASES. 8

HIDROLASES: as principais são proteases. Elas catalizam o rompimento das ligações pépticas por abaixamento do ponto isoelétrico da proteína (é o ponto em que as cargas elétricas se equivalem). Há um

mesmo número de radicais $\mathrm{COO}^{-} \mathrm{e}$ $\mathrm{NH}+$ nesse caso. Tôdas as proteinas possuem um ponto isoelétrico que mantém o equilibrio das ligações. Quando êle é diminuído, as ligações se desfazem e produz-se a hidrólise da proteina. Segundo alguns autores, as proteases seriam as responsáveis pela destruição da matriz orgânica do esmalte desde que as bactérias tenham penetrado nas lamelas. As colagenases desenvolvem intensa atividade no periodonto. ${ }^{8}$

DESMOLASES: as principais são:

- a) decarboxilases - favorecidas pelo $\mathrm{pH}$ ácido decorrente de processos inflamatórios. Atuam formando ptomaínas, cadaverina etc., tornando o pH alca- 
lino e facilitando a ação das desaminases.

- b) desaminases - Liberam radicais $\mathrm{NH}_{3}$. Daí o fato de encontrarmos na polpá dentária infetada, gases como o $\mathrm{CO}_{2} \mathrm{e}$ radicais $\mathrm{NH}_{3}$. Desta forma ácidos aminados sulfurados formam $\mathrm{H}_{2} \mathrm{~S}$ e triptofânio.

- c) outras: transaminases e transmetilases.

Um aspecto de suma importância da degradação protéica por bactérias é o que diz respeito à identificação bacteriana por provas bioquímicas. Em Taxionomia (identificação e classificação) há várias provas bioquímicas onde é testada a atividade proteolítica das bactérias. 0 resultado de sua ação é a formação de diversos produtos finais que são observados, alguns com auxílio de reagentes, outros diretamente. São, por exemplo, as provas de liquefação da gelatina, indol, $\mathrm{H}_{2} \mathrm{~S}$, ação sôbre o leite etc.

A importância do estudo da P U T R E F A C Ã O em Odontologia, se não transcende, nivela-se ao da F E R M E N T A C Ã O.

Foi pretendido por uma corrente de autores que a origem da cárie dentária seria por ação de bactérias proteolíticas sôbre a porção orgânica (matriz) do esmalte dentário. Estas bactérias, através de suas enzimas proteolíticas e aminolíticas degradariam a matriz orgânica determinando a cárie. Hoje, esta hipótese está totalmente abandonada já que houve uma confirmação experimental de que o início da cárie dental é, realmente, fruto da ação de ácidos produzidos por bactérias sôbre a porção inorgânica (prismas) do esmalte. Contudo, embora as bactérias proteolíticas não atuem na determinação do início do processo cárie, elas o fazem após, quando do desenvolvimento do mesmo. Sobretudo quando a cárie atinge a dentina que é riquíssima em material orgânico. 5

Como se isso não bastasse, na evolução do processo carioso, uma primeira conseqüência é o ataque a um tecido mole de natureza protéica que se situa no interior do dente. a lesão do tecido pulpar ou polpa dental. Neste local, as bactérias, com o campo de ação mais livre, produzem a degradação da polpa.

Além dos relacionamentos com a cárie dental e suas conseqüências, as bactérias proteolíticas parecem estar ìntimamente relacionadas com a doença periodontal. o Bacteroides melaninogenicus, por exemplo, é um bacilo Gram negativo que habita o sulco gengival; êle produz a COLAGENASE, uma enzima capaz de desdobrar o colágeno. 9

Outras lesões com sede na bôca (estomatites) podem ser agravadas pela presença de bactérias proteolíticas que produzem a destruição dos tecidos moles. Podem, também, serem determinadas por elas.

Salientamos assim, sem maiores detalhes, o alto significado da ação das bactérias proteolíticas com relação à Odontologia tanto no processo carioso com suas conseqüências como nas periodontopatias e estomatites, pois êstes assuntos serão objeto de estudo posterior. 8 


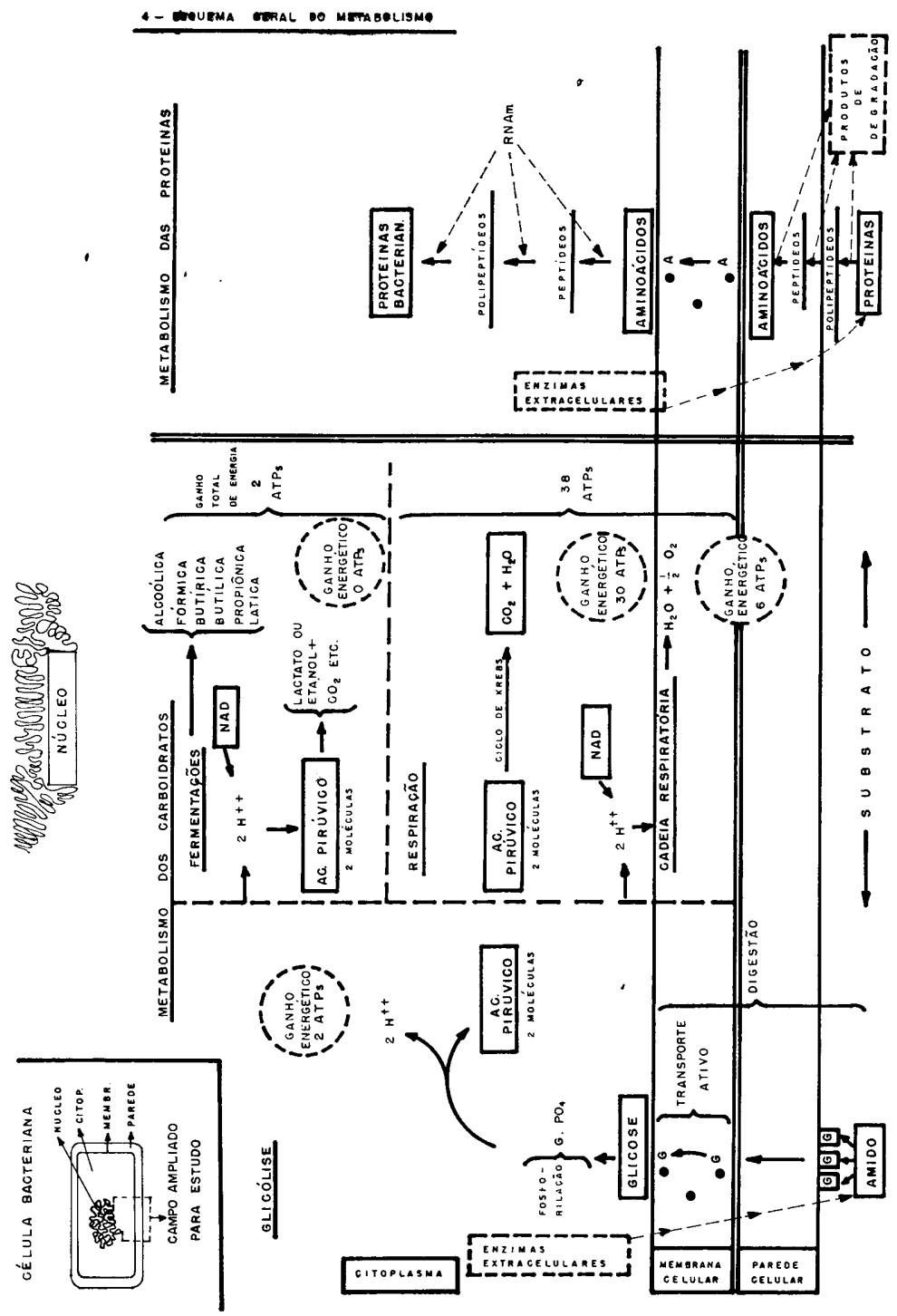

R. Fac, Odont, P. A. 
SYNOPSIS

Study and description of the bacterial metabolism. Material of study to students who take up MICRO.
BIOLOGY in Dental Schols. Association of metabolic phenomenon of bacteria with the most common pathologic process in Dentistry: dental caries and its consequences, and, periodontal disease.

\section{REFERÊYCIAS BIBLIOGRÁFICAS}

1. BACILA, M. Curso de fisiologia de microrganismos. Curitiba, I.B.U.P., 1960.

2. BIER, O. Bacteriologia e imunologia. 13. ed. São Paulo, Melhoramentos, 1966. p. 29-58.

3. BURNETT, G. W. \& SCHERP, H. W. Oral microbiology and infectious disease 2 2.ed. Baltimore, Williams \& Wilkins Company, 1962. p. 91-118.

4. BURRows, W. Textbook of microbiology. 8.ed. Philadelphia, Saunders, 1963. p. 157-159.

5. DE ARAÚJO, W. C. Emprêgo de animais assépticos, gnobióticos e convencionais na pesquisa da cárie dental. Revista Brasileira de Odontologia, Rio de Janeiro, 25:275-283, 1966.

6. JAWETZ, E. et alii. Microbiologia médica. Rio de Janeiro, Guanabara Koogan, 1968. p. 55-67.

7. LAMANNA, C. \& MALleTE, M. F. Basic bacteriology. 2.ed. Baltimore, Williams \& Wilkins Company, 1959. p. 581-764.

8. LOURO $F^{\circ}$, P. A. et alii. Guia para o estudo de microbiologia. Pôrto Alegre, Cadeira de Microbiologia da Faculdade de Odontologia, UFRGS, 1966. p. 21-34.

9. MAC DONALD, J. B. et alii. Aspects of the pathogenesis of mixed anaerobic infections of mucous menbranes. Journal of Dental Research, Chicago, 42:529-543, 1963.

10. OGINSKY, E. L. \& UMBREIT, W. W. An introduction to bacterial physiology. 2.ed. San Francisco, W. H. Freeman and Company, 1959. p. $235-265$.

11. WHITE, A. et alii. Principles of biochemistry. 2.ed. New York, McGraw Hill Book Company Inc., 1959. p. 13-52.

R. Fac. Odont. P. A. 